\title{
GREATER SAGE-GROUSE SELECT NEST SITES TO AVOID VISUAL PREDATORS BUT NOT OLFACTORY PREDATORS
}

\author{
Michael R. Conover ${ }^{1}$, Jennifer S. Borgo, Rebekah E. Dritz, \\ Jonathan B. Dinkins, AND David K. Dahlgren \\ Department of Wildland Resources, Utah State University, Logan, UT 84322-5230
}

\begin{abstract}
Birds can hide from visual predators by locating nests where there is cover and from olfactory predators where habitat features create updrafts, high winds, and atmospheric turbulence, but sites optimal for hiding from visual and olfactory predators often differ. We examined how Greater Sage-Grouse (Centrocercus urophasianus) balance the dual needs of hiding from both visual and olfactory predators on Parker Mountain, Utah, where the Common Raven (Corvus corax) is the main visual predator and the striped skunk (Mephitis mephitis) and American badger (Taxidea taxus) are the main olfactory predators. By comparing nest sites to random sites during 2005 and 2006, we found that sage-grouse nest at sites where their nests were obscured from visual predators but were exposed to olfactory predators. To validate these findings, we replicated the study in southwest Wyoming during 2008. Again, we found that visual obscurity at nest sites was greater than at control sites but olfactory obscurity was less. Our results indicate that Greater Sage-Grouse select nest sites where they will be concealed from visual predators but at the cost of locating nests where they are exposed to olfactory predators. In southwest Wyoming, we found that olfactory predators (mammals) and visual predators (birds) depredated an equal number of nests. By selecting nest sites with visual obscurity, Greater Sage-Grouse have reduced the threat from visual predators to where it was similar to the threat posed by olfactory predators.
\end{abstract}

Key words: Centrocercus urophasianus, nest depredation, nest-site characteristics, olfactory predators, sage-grouse, visual predators.

\section{Centrocercus urophasianus Selecciona Sitios de Anidación para Evitar Depredadores Visuales pero no Depredadores Olfatorios}

Resumen. Las aves pueden esconder sus nidos de depredadores visuales localizándolos en sitios con cobertura y de depredados olfatorios donde las características del hábitat crean corrientes de aire, vientos fuertes o turbulencia atmosférica, pero los sitios con características óptimas para esconder los nidos de cada tipo de depredador generalmente son diferentes. Examinamos como Centrocercus urophasianus evalúa las necesidades de esconder sus nidos ante depredadores visuales y olfatorios en las montañas Parker, estado de Utah, donde el cuervo Corvus corax es el principal depredador visual mientras que los mamíferos Mephitis mephitis y Taxidea taxus son los principales depredadores olfatorios. Al comparar las características de los sitios de anidación con las de sitios al azar durante 2005 y 2006 , encontramos que los nidos de C. urophasianus se encontraban escondidos de depredadores visuales pero que estaban expuestos a depredadores olfatorios. Para validar estos hallazgos, replicamos el estudio en el sudoeste de Wyoming en 2008. Nuevamente encontramos que la cobertura visual en los nidos era mayor que para sitios al azar, pero que la cobertura olfatoria era menor. Nuestros resultados indican que C. urophasianus selecciona los sitios de anidación con características que esconden los nidos de depredadores visuales pero a costa de localizar los nidos en sitios expuestos a depredadores olfatorios. En el sudoeste de Wyoming, encontramos que los depredadores olfatorios (mamíferos) y visuales (aves) depredaron la misma cantidad de nidos. Al seleccionar sitios de anidación con cobertura visual, C. urophasianus ha reducido el riesgo de depredación por depredadores visuales a un nivel similar al del riesgo impuesto por los depredadores olfatorios.

\section{INTRODUCTION}

Nest depredation is the main reason why Greater Sage-Grouse (Centrocercus urophasianus) nests fail (Gregg et al. 1994, Schroeder and Baydack 2001, Holloran et al. 2005). Sagegrouse nest success depends upon the hen's ability to place its nest where predators will not find it, but nest predators use different modalities to locate nests. Many nest predators use vision to locate nests (hereafter called visual predators), while others use odor cues to locate nests when atmospheric conditions favor the use of this modality (hereafter called olfactory predators). Olfactory predators include many mammals, such as the feral hog (Sus scrofa), striped skunk (Mephitis mephitis), and American badger (Taxidea taxus) (Conover 2007).

Manuscript received 10 September 2009; accepted 24 November 2009.

1E-mail: mike.conover@usu.edu

The Condor, Vol. 112, Number 2, pages 331-336. ISSN 0010-5422, electronic ISSN 1938-5422. @ 2010 by The Cooper Ornithological Society. All rights reserved. Please direct all requests for permission to photocopy or reproduce article content through the University of California Press's Rights and Permissions website, http://www.ucpressjournals.com/ reprintInfo.asp. DOI: $10.1525 /$ cond.2010.090172 
Visual predators detect nests in their line of sight, and birds can hide their nests from them by locating their nests in cover. Odors, however, move on air currents and can flow around obstacles that impede vision. This does not mean that all nest sites are equally vulnerable to olfactory predators. Olfactory predators have difficulty finding odor sources where there are updrafts, high wind speeds, and atmospheric turbulence because these conditions disrupt and disperse plumes of odor (Conover 2007). These atmospheric conditions are influenced by habitat, and birds can hide their nests from olfactory predators by nesting where habitat features create updrafts and turbulence. Unfortunately for nesting birds, sites optimal for hiding from visual predators usually differ from sites optimal for hiding from olfactory predators. For instance, in the arid West updrafts are more likely to occur on south-facing slopes because they are warmer than north-facing sites during the day and early evening. Hence, nests on south-facing slopes should be less vulnerable to olfactory predators than nests on north-facing slopes. Concomitantly, vegetation is thicker on north-facing slopes because these slopes retain more moisture, and nests located on north-facing slopes should be safer from visual predators than nests on south-facing slopes. These predictions seem to be correct at least for artificial nests. In Utah, Conover (2007) found artificial nests on south-facing slopes to be depredated primarily by visual predators, nests on north-facing slopes to be depredated primarily by olfactory predators.

Greater Sage-Grouse nests are depredated by both visual nest predators, such as Common Ravens (Corvus corax), and olfactory predators, such as badgers and skunks (Schroeder and Baydack 2001, Holloran et al. 2005, Mezquida et al. 2006 , Coates et al. 2007). The objective of our study was to examine how Greater Sage-Grouse balance their dual needs to hide their nests from both visual and olfactory predators. We predicted that if visual predators pose the greater threat to their nests, then hens should place their nests where they are visually obscure. Alternatively, if olfactory predators pose the greater threat, then hens should place their nests where they are hidden from these predators.

\section{METHODS}

\section{STUDY AREAS}

This study was conducted during 2005 and 2006 on Parker Mountain, in the largest contiguous area of sagebrush (Artemisia spp.) steppe in Utah. It spanned the Aquarius and Awapa plateaus in central Utah at an elevation of 2130 to $3010 \mathrm{~m}$, with most Greater Sage-Grouse leks occurring from 2400 to $2700 \mathrm{~m}$ in elevation. Most (95\%) of Parker Mountain's 107 000 ha was publicly owned and managed by either the U.S. Forest Service, U.S. Bureau of Land Management, or Utah's School and Institutional Trust Lands Administration (Chi 2004). Black sagebrush (A. nova) and Wyoming big sagebrush
(A. tridentata wyomingensis) dominated the lower elevations, while mountain big sagebrush (A. tridentata vaseyana) and silver sagebrush (A. cana) were common at higher elevations. Common forbs included cinquefoil (Potentilla spp.), phlox (Phlox spp.), dandelion (Taraxacum spp.), lupine (Lupinus spp.), daisy (Erigeron spp.), and milkvetch (Astragalus spp.). Common grass species included wheatgrass (Agropyron spp.), bluegrass (Poa spp.), grama (Bouteloua spp.), squirrel tail (Hordeum spp.), and June grass (Koeleria spp.; Dahlgren 2006).

In 2008, we replicated the Parker Mountain study in southwest Wyoming in Lincoln, Sweetwater, and Uinta counties, which cover $>43000 \mathrm{~km}^{2}$. This study area was along the eastern edge of the Bear River Divide at elevations between 1950 and $2520 \mathrm{~m}$, with most sage-grouse leks occurring from 1960 to $2220 \mathrm{~m}$ in elevation. The landscape was dominated by sagebrush; Wyoming big sagebrush and mountain big sagebrush were the most common. Black sagebrush (Artemisia nova) was found on exposed ridges, and silver sagebrush occurred in wetter areas. Other common shrub species in the Wyoming study area included antelope bitterbrush (Purshia tridentata), snowberry (Symphoricarpos albus), winterfat (Ceratoides lanata), green rabbit brush (Chrysothamnus viscidiflorus), gray rabbit brush (C. nauseosus), and greasewood (Sarcobatus vermiculatus). Common forbs were dandelion, common yarrow (Achillea millefolium), buckwheat (Eriogonum spp.), phlox, and lupine. Common grass species included bluegrass, wheatgrass, needlegrass (Stipa spp.), and cheatgrass (Bromus tectorum). Isolated stands of juniper (Juniperus spp.) and aspen (Populus tremuloides) were found on some hillsides.

\section{FIELD METHODS}

We captured Greater Sage-Grouse hens during the spring at night by use of spotlights and long-handled nets (Giesen et al. 1982). Captured hens were fitted with 17.5 -g to 22 -g necklace radios. We located radio-marked hens by using receivers and either a hand-held 3-element Yagi antenna or a vehiclemounted omni-directional antenna. We relocated hens every other day until we found their nests. Once we found a nest, we checked it every other day to determine if it was still being incubated. Nests were checked at a distance so that we would not disturb the hen or leave an odor trail to the nest (Holloran et al. 2005). We checked each nest to determine its fate once incubation was complete. We considered a nest successful if the eggshells included an egg cap remaining in the nest, detached shell membranes, or if we observed the hen with a brood (Griner 1939). We evaluated depredated nests to identify potential nest predators by the remains of the nest, eggshells, scat, tracks, or hair.

We paired each nest with a randomly chosen control site after the hen stopped incubating or after the nest was depredated or abandoned. The control site was $100 \mathrm{~m}$ from the nest. We determined the direction of the control site from the nest 
site by randomly selecting a number between 0 and 359 from a random-number table, with each number representing one degree on a compass and $0^{\circ}$ being magnetic north. At the control site, we placed a pseudo-nest under the nearest bush within $1 \mathrm{~m}$ of that point. Hereafter, we call both the pseudo-nests at control sites and sage-grouse nests at nest sites nest bowls.

We used a cover board to measure both vertical and horizontal concealment at nest and control sites. The cover board was a $10-\times 10-\mathrm{cm}$ white square with vertical and horizontal black lines spaced $1 \mathrm{~cm}$ apart so that they created 100 points where the vertical and horizontal lines crossed. We measured horizontal concealment by placing the cover board in the nest bowl perpendicular to the ground. We counted the number of points that were obscured from view when we looked at the nest bowl from a distance of $1.5 \mathrm{~m}$ and a height of $1 \mathrm{~m}$. We repeated this count in each of the cardinal directions, and we used the mean of the four values as a measure of horizontal concealment. We measured vertical concealment by placing the cover board in the nest bowl so that it was parallel to the ground. We then looked down at the cover board from a height of $1.5 \mathrm{~m}$ directly above it and recorded the number of the nest card's points that were concealed. We also measured the height of the tallest plant within $1 \mathrm{~m}$ of the nest bowl.

We wanted to determine whether Greater Sage-Grouse selected nest sites where habitat features enhanced updrafts, wind speeds, and turbulence. We compared the relative wind velocities and atmospheric turbulence at each nest site and its paired control site by making simultaneous measurements at both. Using two sonic anemometers (Campbell Scientific Company, North Logan, UT), we made measurements as soon as possible after the hen stopped incubating the nest. These anemometers recorded instantaneous wind velocities on an $x$, $y$, and $z$ axis every sec for $30 \mathrm{~min}$; the $x$ axis was aligned with magnetic north. These measurements were converted to standard measurements of wind velocity (Conover 2007): $w^{\prime}$ was the instantaneous vertical movement of air along the $z$ axis, with a positive number resulting from an updraft and a negative number from a downdraft; $u^{\prime}$ was the instantaneous wind speed in a horizontal direction and measured as the square root of $x^{2}+y^{2}$. From these values, we calculated the mean vertical wind velocity $(W)$, horizontal wind velocity $(U)$, turbulence $(T)$, which was the standard deviation of $U$, and turbulence intensity $(T / U)$, which was turbulence corrected for mean horizontal wind speed. Turbulence measured how much an odor plume can disperse on the basis of time elapsed since an odorant is released from a source. Turbulence intensity measured how much an odor plume can disperse on the basis of the distance it has traveled from its source.

We replicated the Parker Mountain study during 2008 in southwest Wyoming to determine if the results obtained at Parker Mountain were applicable to other areas. Our methods in Wyoming were identical to those we employed earlier on Parker Mountain.

\section{STATISTICAL ANALYSES}

At the Utah study area, we used paired Student's $t$-tests to compare characteristics of nest sites to those of paired control sites. We compared the characteristics of successful nests to those of unsuccessful nests with unpaired Student $t$-tests and considered results significant if $P<0.05$.

We analyzed data from Wyoming separately from those from Utah because they originated from different areas in different years. Student's $t$-tests were used to compare the characteristics of nest sites to those of paired control sites and to compare the characteristics of successful nests to those of unsuccessful ones. We considered a finding to be valid only if it was statistically significant at both study areas.

\section{RESULTS}

\section{PARKER MOUNTAIN, UTAH}

We located 20 Greater Sage-Grouse nests and paired them with 20 control sites. The visual characteristics of nest sites differed from those of control sites. Nest sites had taller vegetation and were more concealed vertically than control sites, but nest sites and control sites had similar levels of horizontal concealment (Table 1). The olfactory characteristics of nest sites differed from those of paired control sites. Horizontal wind velocities and turbulence at nest sites were lower than at control sites (Table 1). Vertical wind velocity and turbulence intensity at nest sites and control sites were similar.

Of the 20 Greater Sage-Grouse nests on Parker Mountain, twelve were successful in hatching at least one egg, six were unsuccessful, and two were abandoned because of investigator interference. All unsuccessful nests were depredated, but we were unable to identify which predator species were responsible. The visual and olfactory characteristics of the twelve successful nests were similar to those of the six unsuccessful nests (Table 2).

\section{SOUTHWEST WYOMING}

We located 24 Greater Sage-Grouse nests in southwest Wyoming during 2008. Nest sites were located by taller plants than control sites and had greater vertical and horizontal concealment than control sites (Table 1). The olfactory characteristics of nest sites and control sites also differed. Updrafts predominated at nest sites (i.e., $W$ was positive), while downdrafts predominated at control sites (i.e., $W$ was negative). Vertical wind velocities, horizontal wind velocities, and turbulence were lower at nest sites than at control sites.

Of the 24 Greater Sage-Grouse nests in Wyoming, twelve were successful and twelve were unsuccessful. All unsuccessful nests were depredated, five by mammals, five by birds, and two by unidentified predators. Successful nests were similar to unsuccessful nests in their visual and olfactory characteristics (Table 2). 
TABLE 1. Characteristics of Greater Sage-Grouse nests and paired control sites on Parker Mountain, Utah (2005 and 2006) and in Wyoming (2008) and the results of paired Student's $t$-tests that compare them to each other.

\begin{tabular}{|c|c|c|c|c|c|c|}
\hline \multirow[b]{2}{*}{ Study area and characteristics } & \multicolumn{2}{|c|}{ Nest site } & \multicolumn{2}{|c|}{ Control site } & \multirow[b]{2}{*}{$t$} & \multirow[b]{2}{*}{$P$} \\
\hline & $\bar{x}$ & SE & $\bar{x}$ & SE & & \\
\hline \multicolumn{7}{|l|}{ Utah ( $n=20$ pairs of nests and control sites $)$} \\
\hline \multicolumn{7}{|l|}{ Visual characteristics } \\
\hline Height of shrub (m) & 0.74 & 0.06 & 0.37 & 0.07 & 4.37 & 0.0003 \\
\hline Vertical concealment $(\%)$ & 34 & 5 & 7 & 2 & 4.91 & 0.0001 \\
\hline Horizontal concealment (\%) & 50 & 6 & 30 & 8 & 1.94 & 0.07 \\
\hline \multicolumn{7}{|l|}{ Olfactory characteristics } \\
\hline Vertical wind velocity or $W\left(\mathrm{~m} \mathrm{sec}^{-1}\right)$ & $-0.06^{\mathrm{a}}$ & 0.07 & 0.15 & 0.03 & 1.16 & 0.26 \\
\hline Horizontal wind velocity or $U\left(\mathrm{~m} \mathrm{sec}^{-1}\right)$ & 1.48 & 0.23 & 2.08 & 0.31 & 2.92 & 0.009 \\
\hline Turbulence $(\operatorname{SD}$ of $U)$ & 0.67 & 0.09 & 0.78 & 0.08 & 2.97 & 0.008 \\
\hline Turbulence intensity (turbulence/ $U$ ) & 0.48 & 0.04 & 0.41 & 0.02 & 1.81 & 0.08 \\
\hline \multicolumn{7}{|l|}{ Wyoming ( $n=24$ pairs of nests and control sites) } \\
\hline \multicolumn{7}{|l|}{ Visual characteristics } \\
\hline Height of shrub (m) & 0.72 & 0.04 & 0.40 & 0.04 & 5.70 & 0.0001 \\
\hline Vertical concealment (\%) & 69 & 5 & 2 & 1 & 13.43 & 0.0001 \\
\hline Horizontal concealment $(\%)$ & 82 & 5 & 15 & 5 & 11.30 & 0.0001 \\
\hline \multicolumn{7}{|l|}{ Olfactory characteristics } \\
\hline Vertical wind velocity or $W\left(\mathrm{~m} \mathrm{sec}^{-1}\right)$ & $0.04^{\mathrm{a}}$ & 0.03 & -0.08 & 0.02 & 4.41 & 0.0002 \\
\hline Horizontal wind velocity or $U\left(\mathrm{~m} \mathrm{sec}^{-1}\right)$ & 0.89 & 0.17 & 1.44 & 0.16 & 2.20 & 0.04 \\
\hline Turbulence (SD of $U$ ) & 0.50 & 0.06 & 0.72 & 0.06 & 3.00 & 0.007 \\
\hline Turbulence intensity (turbulence $/ U$ ) & 0.62 & 0.02 & 0.54 & 0.02 & 2.13 & 0.04 \\
\hline
\end{tabular}

${ }^{a}$ A negative value for vertical wind velocity indicates a downdraft, a positive value indicates an updraft.

TABLE 2. Comparison of characteristics of successful and unsuccessful Greater Sage-Grouse nests on Parker Mountain, Utah (2005 and 2006), in Wyoming (2008) and the results of unpaired Student's $t$-tests.

\begin{tabular}{|c|c|c|c|c|c|c|}
\hline \multirow[b]{2}{*}{ Study area and characteristics } & \multicolumn{2}{|c|}{ Unsuccessful } & \multicolumn{2}{|c|}{ Successful } & \multirow[b]{2}{*}{$t$} & \multirow[b]{2}{*}{$P$} \\
\hline & $\bar{x}$ & SE & $\bar{x}$ & SE & & \\
\hline \multicolumn{7}{|l|}{ Utah ( $n=20$ pairs of nests and control sites) } \\
\hline \multicolumn{7}{|l|}{ Visual characteristics } \\
\hline Height of shrub (m) & 0.74 & 0.11 & 0.71 & 0 & 0 & 0.84 \\
\hline Vertical concealment $(\%)$ & 29 & 10 & 36 & 6 & 0.70 & 0.49 \\
\hline Horizontal concealment $(\%)$ & 39 & 11 & 49 & 8 & 0.72 & 0.48 \\
\hline \multicolumn{7}{|l|}{ Olfactory characteristics } \\
\hline Vertical wind velocity or $W\left(\mathrm{~m} \mathrm{sec}^{-1}\right)$ & $-0.21^{\mathrm{a}}$ & 0.22 & 0.00 & 0.03 & 1.31 & 0.21 \\
\hline Horizontal wind velocity or $U\left(\mathrm{~m} \mathrm{sec}^{-1}\right)$ & 1.72 & 0.50 & 1.27 & 0.30 & 0.81 & 0.43 \\
\hline Turbulence (SD of $U$ ) & 0.72 & 0.16 & 0.62 & 0.12 & 0.51 & 0.62 \\
\hline Turbulence intensity (turbulence/ $U$ ) & 0.43 & 0.10 & 0.51 & 0.04 & 0.87 & 0.40 \\
\hline \multicolumn{7}{|l|}{ Wyoming ( $n=24$ pairs of nests and control sites) } \\
\hline \multicolumn{7}{|l|}{ Visual characteristics } \\
\hline Height of shrub (m) & 0.80 & 0.07 & 0.65 & 0.08 & 1.83 & 0.08 \\
\hline Vertical concealment $(\%)$ & 68 & 7 & 70 & 8 & 0.13 & 0.90 \\
\hline Horizontal concealment (\%) & 79 & 8 & 86 & 5 & 0.92 & 0.37 \\
\hline \multicolumn{7}{|l|}{ Olfactory characteristics } \\
\hline Vertical wind velocity or $W\left(\mathrm{~m} \mathrm{sec}^{-1}\right)$ & $0.05^{\mathrm{a}}$ & 0.06 & 0.03 & 0.02 & 0.30 & 0.76 \\
\hline Horizontal wind velocity or $U\left(\mathrm{~m} \mathrm{sec}^{-1}\right)$ & 0.98 & 0.34 & 0.79 & 0.11 & 0.53 & 0.60 \\
\hline Turbulence $(\mathrm{SD}$ of $U$ ) & 0.50 & 0.11 & 0.50 & 0.07 & 0 & 1.00 \\
\hline Turbulence intensity (turbulence $/ U$ ) & 0.60 & 0.03 & 0.64 & 0.03 & 0.68 & 0.50 \\
\hline
\end{tabular}

${ }^{a}$ A negative value for vertical wind velocity indicates a downdraft, a positive value indicates an updraft. 


\section{DISCUSSION}

We examined how Greater Sage-Grouse balance the dual needs of hiding their nests both from visual and olfactory predators on Parker Mountain, Utah, and replicated the study in southwest Wyoming. We took the conservative approach of rejecting the null hypothesis of no effect only if the results were statistically significant at both study sites, believing this approach was needed to avoid a type I statistical error.

At both study sites, we found that Greater Sage-Grouse preferred to locate nests where the nests were obscured from visual predators. Our findings are not unique. Gregg et al. (1994), Sveum et al. (1998), Horran et al. (2005), Lane (2005), and other studies have reported that Greater Sage-Grouse select nest sites that are under tall shrubs and where cover visually obscures their nests.

Birds also need to hide their nests from olfactory predators and can do so by locating their nests where updrafts, increased turbulence, and high wind velocities occur because these conditions cause odor plumes to disperse rapidly (Conover 2007). Yet, we found that sites of Greater Sage-Grouse nest in both our Utah and Wyoming study areas had similar updrafts, lower horizontal wind speeds, and less turbulence than did control sites. We hypothesize that sage-grouse select sites where their nests will be visually hidden but at the cost of locating them where they are exposed to olfactory predators (predator-avoidance hypothesis). Alternatively, sage-grouse may be selecting sites with lower wind speeds and turbulence to optimize temperatures in the nest (temperature-optimization hypothesis). In Arizona, Gila Woodpeckers (Melanerpes uropygialis) and Elf Owls (Micrathene whitneyi) nest in cavities on the north side of cacti or trees, presumably because such cavities are cooler during the day than south-facing ones (Inouye et al. 1981, Hardy and Morrison 2001). In cooler areas, Red-naped Sapsuckers (Sphyrapicus nuchalis), Williamson's Sapsuckers (S. thyroideus), and Northern Flickers (Colaptes auratus) orient the entrances of their nest cavities toward the south, presumably to maximize the amount of sunlight reaching them (Crockett and Hadow 1975, Inouye 1976, Wiebe 2001). Of course, both the predator-avoidance and temperature-optimization hypotheses need additional testing with sage-grouse before either can be accepted.

In Wyoming, we found that visual predators (birds, such as the Common Raven) and olfactory predators (mammals, such as badgers) depredated the same number of Greater SageGrouse nests. Although our method of identifying predators may have led to some error, others studies have also used the remains of the nest, eggshells, scat, tracks, or hair to identify predators that depredated the nests of Greater Sage-Grouse (Slater 2003, Kuipers 2004, Moynahan 2004). Our finding that five nests were depredated by avian predators and five by mammalian predators was similar to that of a camera study in Nevada, in which ten nests were depredated by Common Ravens and seven by badgers (Coates et al. 2008). In Wyoming,
Holloran and Anderson (2003) placed cameras on 26 sagegrouse nests; three were depredated. The badger, Black-billed Magpie (Pica hudsonia), and elk (Cervus canadensis) each depredated one nest. Holloran and Anderson (2003) also reported that their cameras documented Richardson's (Spermophilus richardsonii) and thirteen-lined (S. tridecemlineatus) ground squirrels at nest sites, but no nests were depredated by ground squirrels. These scant data suggest that olfactory predators (badgers) and visual predators (ravens and magpies) pose similar threats to the nests of Greater Sage-Grouse. Conover (2007) argued that birds should follow an optimal-hiding strategy and locate nests where the combined threat of visual and olfactory predators is minimized. He also hypothesized that this would be achieved when visual and olfactory predators pose a similar threat of depredating nests. If Conover's hypothesis is correct, then Greater Sage-Grouse seem to be selecting nest sites optimally, given that visual predators and olfactory predators seem to be depredating similar numbers of nests.

We are unaware of any other study that has examined the olfactory characteristics of nest sites. However, Conover and Borgo (2008) found that sites where Sharp-tailed Grouse (Tympanuchus phasianellus) loaf differed from control sites in characteristics (i.e., greater updrafts, wind velocities, and turbulence) that would help hide a grouse from olfactory predators, but loafing sites were similar to control sites in characteristics (i.e., vertical and horizontal concealment) that would hide a grouse from visual predators. Why Greater Sage-Grouse and Sharp-tailed Grouse select for different characteristics is unclear. Perhaps it is due to species differences or because eggs are more vulnerable to visual predators, while loafing adults are more vulnerable to olfactory predators.

\section{ACKNOWLEDGMENTS}

We thank the Jack H. Berryman Institute and the Utah Agricultural Experiment Station for funding this study. L. Mastro and M. Guttery helped in data collection.

\section{LITERATURE CITED}

ChI, R. Y. 2004. Greater Sage-Grouse reproductive ecology and tebuthiuron manipulation of dense big sagebrush on Parker Mountain. M. Sc. thesis, Utah State University, Logan, UT

Coates, P. S., J. W. Connelly, and D. J. Delehanty. 2008. Predators of Greater Sage-Grouse nests identified by video monitoring. Journal of Field Ornithology 79:421-428.

Coates, P. S., J. O. Spencer JR., AND D. J. Delehanty. 2007. Efficacy of CPTH-treated egg baits for removing ravens. HumanWildlife Conflicts 1:224-234.

Conover, M. R. 2007. Predator-prey dynamics: the use of olfaction. Taylor and Francis, Boca Raton, FL.

Conover, M. R., AND J. S. Borgo. 2008. Do Sharp-tailed Grouse select loafing sites to avoid visual or olfactory predators? Journal of Wildlife Management 73:242-247.

Crockett, A. A., AND H. H. Hadow. 1975. Nest site selection by Williamson and Red-naped sapsuckers. Condor 77:365-368. 
DAHLGREN, D. K. 2006. Greater Sage-Grouse reproductive ecology and response to experimental management of mountain big sagebrush on Parker Mountain, Utah. M.Sc. thesis, Utah State University, Logan, UT.

INOUYE, D. W. 1976. Nonrandom orientation of entrance holes to woodpecker nests in aspen trees. Condor 78:101-102.

InOUYe, R. S., N. J. HuntLy, AND D. W. InOuYE. 1981. Non-random orientation of Gila Woodpecker nest entrances in saguaro cacti. Condor 83:88-89.

Giesen, K. M., T. J. Schoenberg, and C. E. Braun. 1982. Methods for trapping Sage-Grouse in Colorado. Wildlife Society Bulletin 10:224-231.

Gregg, M. A., J. A. Crawford, M. S. Drut, and A. K. Delong. 1994. Vegetational cover and predation of Sage Grouse nests in Oregon. Journal of Wildlife Management 58:162-166.

GRINER, L. S. 1939. A study of Sage Grouse (Centrocercus urophasianus), with special reference to life history, habitat requirements, and numbers and distribution. M. Sc. thesis, Utah State University, Logan, UT.

Hardy, P. C., AND M. L. Morrison. 2001. Nest site selection in Elf Owls in the Sonoran desert. Wilson Bulletin 113:23-32.

Holloran, M. J., And S. H. Anderson. 2003. Direct identification on Northern Sage-Grouse, Centrocercus urophasianus, nest predators using remote sensing cameras. Canadian Field-Naturalist 117:308-310

Holloran, M. J., B. J. Heath, A. G. Lyon, S. J. Slater, J. L. Kuipers, And S. H. Anderson. 2005. Greater Sage-Grouse nesting habitat selection and success in Wyoming. Journal of Wildlife Management 69:638-649.
KUIPERS, J. L. 2004. Grazing system and linear corridor influences on Greater Sage-Grouse (Centrocercus urophasianus) habitat selection and productivity. M. Sc. thesis, University of Wyoming, Laramie, WY.

LANE, V. R. 2005. Sage-grouse (Centrocercus urophasianus) nesting and brood-rearing sagebrush habitat characteristics in Montana and Wyoming. M. Sc. thesis, Montana State University, Bozeman, MT.

Mezquida, E. T., S. J. Slater, And C. W. Benkman. 2006. SageGrouse and indirect interactions: potential implications of coyote control on Sage-Grouse populations. Condor 108:747759.

MoYNAHAN, B. J. 2004. Landscape-scale factors affecting population dynamics of Greater Sage-Grouse (Centrocercus urophasianus) in north-central Montana, 2001-2004. Ph.D. dissertation, University of Montana, Missoula, MT.

Schroeder, M. A., And R. K. Baydack. 2001. Predation and the management of prairie grouse. Wildlife Society Bulletin 29: 24-32.

Slater, S. J. 2003. Sage-grouse (Centrocercus urophasianus) use of different-aged burns and the effects of coyote control in southwestern Wyoming. M. Sc. thesis, University of Wyoming, Laramie, WY.

Sveum, C. M., W. D. Edge, And J. A. Crawford. 1998. Nesting habitat selection by Sage Grouse in south-central Washington. Journal of Range Management 51:265-269.

WiEBE, K. L. 2001. Microclimate of tree cavity nests: is it important for reproductive success in Northern Flickers? Auk 118: $412-421$. 